\title{
A universal nomenclature for subunits of the RNA polymerase III transcription initiation factor TFIIIB
}

\author{
Ian M. Willis ${ }^{1}$ \\ Department of Biochemistry, Albert Einstein College of Medicine, Bronx, New York 10461, USA
}

At the Cold Spring Harbor Laboratory Meeting on Mechanisms of Eukaryotic Transcription held last summer, Làszlò Tora initiated a discussion about the increasingly bewildering nomenclature used to refer to TATAbinding protein-associated factors (TAFs) in different organisms. This problem was most acute for TAFs involved in transcription by RNA polymerase (Pol) II because of the large (and growing) number of these proteins. However, the existing nomenclature was also problematic for TAFs used in transcription by RNA poymerases I and III. In particular, the frequent naming of TAFs according to their molecular mass, which varies among orthologs, created considerable confusion. Recently, a unified and systematic nomenclature for the Pol II TAFs has been adopted (Tora 2002).

Researchers working on RNA polymerase III have now agreed on a universal nomenclature for the proteins that, together with the TATA-binding factor, TBP, comprise the various forms of the Pol III initiation factor TFIIIB (Table 1). In considering a universal nomenclature for the subunits of TFIIIB, it was widely agreed that the TAF3 designation (where the number denotes Pol III) was not suitable because (1) the $\mathrm{B}^{\prime \prime}$ component is not associated with TBP to any significant degree and (2) the TFIIB-related factor (Brf1), although associated with TBP in most, but not all systems (Hamada et al. 2001), is functionally analogous to a general transcription factor, rather than to any Pol II TAF. The universal nomenclature that has been adopted for TFIIIB subunits addresses these and other issues as follows:

1. The BRF nomenclature has been retained for orthologs and paralogs of Brf1.

2. Orthologs of the $\mathrm{B}^{\prime \prime}$ component have been renamed Bdp1 for TFIIIB double prime, the name given originally to the biochemical fraction containing this polypeptide (Kassavetis et al. 1991).

3. Genes (denoted by all upper-case italicized letters)

1E-MAIL willis@aecom.yu.edu; FAX (718) 430-8565.

Article and publication are at http://www.genesdev.org/cgi/doi/10.1101/ gad.998102. or their protein products (denoted by nonitalicized letters with only the first letter being upper-case) can be additionally annotated when referring to orthologs by applying the two-letter species prefix (Hs, Dm, Ce, Sc, Sp, etc.) as proposed in the unified Pol II TAF nomenclature (Tora 2002).

4. Spliced variants of the subunits, which have been described for HsBRF1 (McCulloch et al. 2000) and HsBDP1 (Kelter et al. 2000; Schramm et al. 2000), are designated by a suffix comprising an underscore, a lower-case ' $\mathrm{v}$,' and a number to denote the variant in accordance with the recommendations of the Human Gene Nomenclature Committee. Thus, the fourth variant of human Brf1 to be identified is designated Brf1_v4.

5. The new TFIIIB subunit nomenclature conforms to the Guidelines for Human Gene Nomenclature (http://www.gene.ucl.ac.uk/nomenclature/ guidelines.html) while satisfying the three-letter naming convention used for Saccharomyces cerevisiae and Schizosaccharomyces pombe. Aside from improved communication between researchers, an important benefit of annotations under the same name is the greatly facilitated cross-referencing of entries in different genome databases.

Table 1. Nomenclature for subunits of TFIIIB ${ }^{a}$

\begin{tabular}{ll}
\hline Former name for protein & New protein name \\
\hline Brf1, TFIIIB70 (yeast), Brf, hBRF, & \\
hTFIIIB90, TAF3C, GTF3B, TAF3B2 & Brf1 \\
BRF2 & Brd1_v2 \\
BRF3 & Brf1_v3 \\
BRF4 & Brf1_v4 \\
BRFU, TFIIIB50, FLJ11052 & Brf2 \\
Tfc5, B", TFIIIB90 (yeast), TFIIIB150 & \\
(human), TAF3B1, TFNR & Bdp1 \\
TFNR exon 15 alternate splicing variant & Bdp1_v2 \\
\hline
\end{tabular}

${ }^{a}$ This nomenclature has been endorsed by the following people: E. Peter Geiduschek, Steven Hahn, Nouria Hernandez, George Kassavetis, Richard Maraia, Robert G. Roeder, Susan Lobo-Ruppert, Michael Schultz, André Sentenac, Martin Teichmann, and Robert J. White. 
Willis

\section{Acknowledgments}

On behalf of the Pol III community, I thank Ruth Lovering from the Human Genome Gene Nomenclature Committee for her advice on guidelines and Stephen Bustin, who kindly agreed to rename butyrate response factors 1 and 2 so that the Brf name could be retained for Pol III transcription factors.

\section{References}

Hamada, M., Huang, Y., Lowe, T.M., and Maraia, R.J. 2001. Widespread use of TATA elements in the core promoters for RNA polymerases III, II, and I in fission yeast. Mol. Cell. Biol. 21: 6870-6881.

Kassavetis, G.A., Bartholomew, B., Blanco, J.A., Johnson, T.E., and Geiduschek, E.P. 1991. Two essential components of the Saccharomyces cerevisiae transcription factor TFIIIB: Transcription and DNA-binding properties. Proc. Natl. Acad. Sci. 88: 7308-7312.

Kelter, A.R., Herchenbach, J., and Wirth, B. 2000. The transcription factor-like nuclear regulator (TFNR) contains a novel 55 -amino-acid motif repeated nine times and maps closely to SMN1. Genomics 70: 315-326.

McCulloch, V., Hardin, P., Peng, W., Ruppert, J.M., and LoboRuppert, S.M. 2000. Alternatively spliced hBRF variants function at different RNA polymerase III promoters. $E M B O$ J. 19: 4134-4143.

Schramm, L., Pendergrast, P.S., Sun, Y., and Hernandez, N. 2000. Different human TFIIIB activities direct RNA polymerase III transcription from TATA-containing and TATAless promoters. Genes \& Dev. 14: 2650-2663.

Tora, L. 2002 A unified nomenclature for TATA box binding protein (TBP)-associated factors (TAFs) involved in RNA polymerase II transcription. Genes \& Dev. 16: 673-675. 


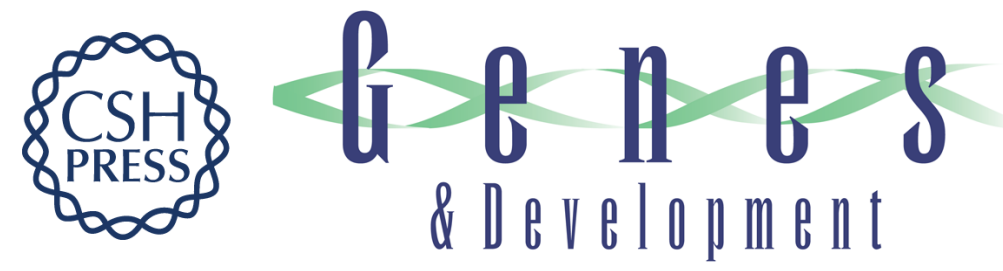

\section{A universal nomenclature for subunits of the RNA polymerase III transcription initiation factor TFIIIB}

Ian M. Willis

Genes Dev. 2002, 16:

Access the most recent version at doi:10.1101/gad.998102

References

This article cites 6 articles, 5 of which can be accessed free at:

http://genesdev.cshlp.org/content/16/11/1337.full.html\#ref-list-1

License

Email Alerting

Receive free email alerts when new articles cite this article - sign up in the box at the top

Service right corner of the article or click here.

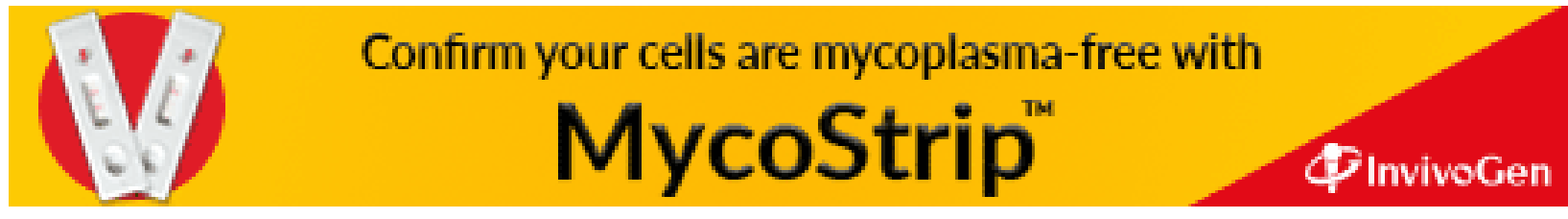

